\title{
The efficacy of suppository versus oral ibuprofen for reducing fever in children
}

\author{
Suhesti Handayani, MD; Sri Rezeki Hadinegoro MD, PhD; \\ Sudigdo Sastroasmoro, MD, PhD
}

\begin{abstract}
Background Ibuprofen suppository is used to reduce fever in children who are unable to receive it orally. The effectiveness of ibuprofen suppository compared to that of oral ibuprofen has not been documented in Indonesian children.

Objective The aim of this study was to compare the efficacy of ibuprofen suppository with that of oral ibuprofen for reducing fever in children.

Methods This study was a randomized clinical trial without blinding on children aged 2-5 years with body weight of 12.5 to $16 \mathrm{~kg}$ who had fever. Subjects received ibuprofen in either oral $(7.5$ $\mathrm{mg} / \mathrm{kg}$ ) or suppository $(125 \mathrm{mg})$ form. The temperature was measured prior to ibuprofen administration, 30 minutes afterwards, and every subsequent half hour until the end of the sixth hour. Any observed adverse effects were recorded.

Results Mean time needed for fever reduction was 2.72 (SD 1.1) hours in the suppository group, compared to 3.43 (SD 0.9) hours in the oral group $(\mathrm{P}=0.004)$. The mean rate of fever reduction in the suppository group was $0.90(\mathrm{SD} 0.4){ }^{\circ} \mathrm{C} /$ hour, while in the oral group it was 0.61 (SD 0.3) ${ }^{\circ} \mathrm{C} /$ hour. However, mean maximum temperature lowering ability did not differ significantly [2.11 (SD 0.7) ${ }^{\circ} \mathrm{C}$ for the suppository group and 1.99 (SD 0.7$){ }^{\circ} \mathrm{C}$, for the oral group $(\mathrm{P}=0.489)$ ]. There was no significant difference in mean duration of effect [220.8 (SD 83.0) hours for the suppository group and 196.6 (SD 92.7) hours for the oral group ( $p=0.231)]$. Conclusions There was no significant difference between both preparations in maximum temperature lowering ability and duration of effect. Temperature reduction was significantly faster with the administration of ibuprofen suppository [Pediatr Indones 2005;45:211-216].
\end{abstract}

Keywords: fever, ibuprofen, children

$\mathrm{F}$ ever is the increase of body temperature beyond the normal circadian range, induced by endogenous pyrogens which trigger the release of prostaglandin by the hypothalamic temperature setting point. A non-steroidal antipyretic agent can reduce prostaglandin synthesis by blocking the cyclooxygenase enzyme. ${ }^{1,2}$

Ibuprofen [2-(4-isobutylphenyl) propionic acid] is effective for reducing prostaglandin biosynthesis, besides having analgesic, antipyretic, and anti-inflammatory effects. In the United States, ibuprofen tablets have been approved for adults and children over 12 years old as a nonprescribed antipyretic drug since 1984. Recently, ibuprofen syrup and tablets have been approved for younger children. ${ }^{3}$

The administration of antipyretics might cause some problems, since children may not be able or refuse to take it, may throw it up, may be suffering from convulsions, or may be under sedation. In such cases, an ibuprofen suppository can be an alternative solution. $4-6$

As of today, there has been no study comparing the effectiveness of ibuprofen suppository to that of oral ibuprofen in Indonesian children. The objective of this study was to compare the antipyretic efficacy of oral ibuprofen to that of the suppository preparation.

From the Department of Child Health, Medical School, University of Indonesia, Jakarta, Indonesia.

Reprint requests to: Sri Rezeki S Hadinegoro, MD, PhD, Infection and Tropical Medicine Division, Department of Child Health, Medical School, University of Indonesia, Cipto Mangunkusumo Hospital, Jl. Salemba No. 6, Jakarta, Indonesia. Tel. 62-21-3918301; Fax. 62-213907743 


\section{Methods}

This study was an open, randomized clinical trial conducted at the outpatient clinic, Department of Child Health, Medical School, University of Indonesia, Cipto Mangunkusumo Hospital, Jakarta from March 1, 2003 until March 31, 2004. Prior approval was obtained from the Ethical Committee of the Medical School, University of Indonesia.

Studied subjects were children suffering from fever for 7 days or less with a body temperature of $38.5-40^{\circ} \mathrm{C}$, aged $24-60$ months, with normal body weight $\left(10^{\text {th }}-90^{\text {th }}\right.$ percentile on the NCHS curve) between 12.5-16 kg, without edema. Parental consent was obtained for all subjects. The subjects had not taken fever reducing medication for the past 6 hours (the previous night), had not taken corticosteroids for at least a week prior to the study, and had not used a fever reducing compress for the past 4 hours. Exclusion criteria were history of convulsion triggered by fever, allergy to ibuprofen or any other non-steroidal analgesic drug, asthma, gastritis, ear infection/auditory canal anatomical defects, cardiac or renal failure, receiving anticoagulant medication, and dehydration.

Subjects who met the inclusion criteria were randomly divided into two groups; group A received oral ibuprofen and group B received ibuprofen suppository. A commercially available ibuprofen preparation (Proris ${ }^{\circledR}$ ) was used. The oral dose was 7.5 $\mathrm{mg} / \mathrm{kg}$ in powder form and the suppository dose was $125 \mathrm{mg}$. Immediately before administering the drug, the first temperature reading $\left(\mathrm{H}_{0}\right)$ was taken. Following drug administration, subjects were placed in an observation room for 6 hours. Subsequent temperature readings were taken every half hour until the end of the $6^{\text {th }}$ hour $\left(\mathrm{H}_{6}\right)$. Temperature readings and adverse effects were recorded by medical personnel. Subjects who developed hyperpyrexia (temperature of $>40^{\circ} \mathrm{C}$ ) during the observation period were dropped out from the study and treated accordingly. Body temperature readings were taken using an infrared ear thermometer (Braun IRT 3020).

The variables used to compare the efficacy of the two forms of medication were $\mathrm{W}_{\text {max }}, \delta \mathrm{t}^{\circ}, \mathrm{K}\left(\delta \mathrm{t}^{\circ}\right)$ $\left.\mathrm{W}_{\max }\right)$, the duration for which the body temperature was kept $<38.5^{\circ} \mathrm{C}$, and the proportion of subjects who reached a body temperature of less than $38.5^{\circ} \mathrm{C}$ within the observation period. $\mathrm{W}_{\max }$ was the time in hours needed to reach the lowest possible body temperature during the observation period. $\delta t^{\circ}$ was the difference in body temperature in ${ }^{\circ} \mathrm{C}$ between the first reading $\left(\mathrm{H}_{0}\right)$ and the lowest body temperature reached within the observation period. $\mathrm{K}\left(\delta \mathrm{t}^{\circ} / \mathrm{Wmax}\right)$ was the rate of body temperature reduction; this was determined by dividing $\delta t^{\circ}$ by Wmax, expressed in ${ }^{\circ} \mathrm{C} /$ hour. The Student's independent t-test was used to analyze data with normal distribution. Data with skewed distribution were analyzed using the Mann-Whitney rank test.

\section{Results}

Eighty children, forty in each group were enrolled as studied subjects. Five subjects dropped out; 2 (one from each group) due to hyperpyrexia, 1 from the oral group due to non-compliance with the study protocol), and 2 (one from each group) did not complete the 6-hour observation period. Finally, 75 subjects were analyzed. Subjects' characteristics are shown in Table 1.

TABle 1. Subjects characteristics

\begin{tabular}{lll}
\hline Characteristics & \multicolumn{2}{c}{ Mean (SD) } \\
\cline { 2 - 3 } & $\begin{array}{l}\text { Oral group } \\
\mathbf{n}=\mathbf{3 6}\end{array}$ & $\begin{array}{l}\text { Suppository group } \\
\mathbf{n}=\mathbf{3 9}\end{array}$ \\
\hline Age (years) & $3.00(0.7)$ & $3.42(0.9)$ \\
Body weight $(\mathrm{kg})$ & $13.25(1.7)$ & $13.88(2.1)$ \\
Pre-treatment body temperature $\left({ }^{\circ} \mathrm{C}\right)$ & $39.04(0.5)$ & $39.18(0.5)$ \\
Length of fever (days) & $3(1-14)^{*}$ & $2(0.5-14)^{\star}$ \\
Dosage (mg/kg body weight) & $7.77(0.8)$ & $9.20(1.3)$ \\
\hline
\end{tabular}

* Mean (range) 


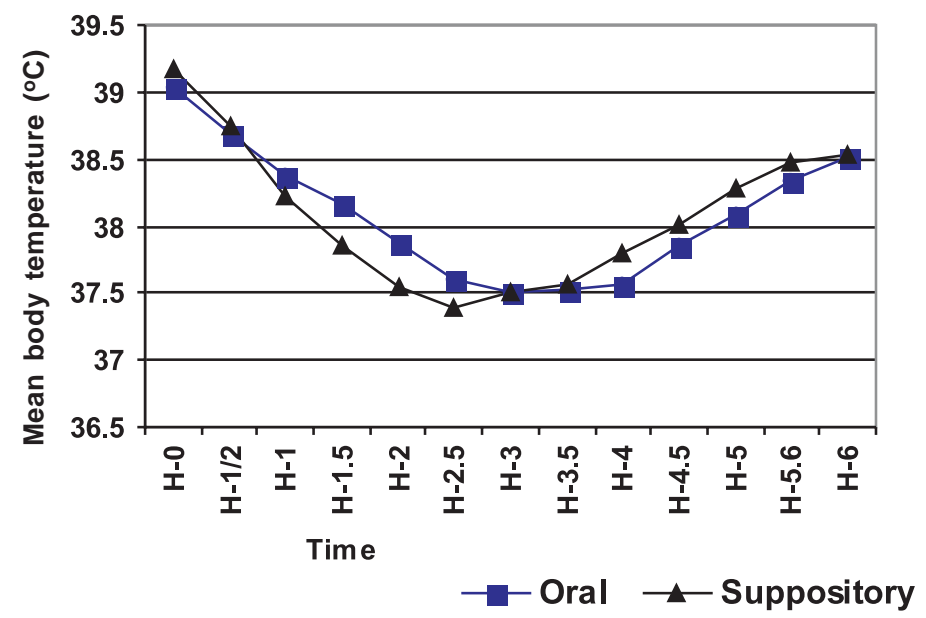

Figure 1. Body TEMPERATURE PATTERN DURING THE OBSERVATION PERIOD

TABLE 2. Comparison OF THE EFFICACY OF ORAL AND SUPPOSITORY IBUPROFEN

\begin{tabular}{llll}
\hline Outcome measure & \multicolumn{1}{c}{ Mean (SD) } & $\mathbf{P}$ \\
\cline { 2 - 3 } & $\begin{array}{l}\text { Oral group } \\
\mathbf{n}=\mathbf{3 6}\end{array}$ & $\begin{array}{l}\text { Suppository group } \\
\mathbf{n}=\mathbf{3 9}\end{array}$ \\
\hline The lowest body temperature reached $\left({ }^{\circ} \mathrm{C}\right)$ & $37.05(0.6)$ & $37.08(0.6)$ & 0.839 \\
$\mathrm{~W}_{\max }$ (hours) & $3.43(0.9)$ & $2.72(1.1)$ & 0.004 \\
$\delta \mathrm{t}^{\circ}\left({ }^{\circ} \mathrm{C}\right)$ & $1.99(0.7)$ & $2.11(0.7)$ & 0.489 \\
$\delta \mathrm{t}^{\circ} \mathrm{W}_{\max }\left({ }^{\circ} \mathrm{C} /\right.$ hour) & $0.61(0.3)$ & $0.90(0.4)$ & 0.001 \\
Effective duration (minutes) & $196.6(92.7)$ & $220.8(83.0)$ & 0.231 \\
\hline
\end{tabular}

The cause of fever was mostly viral infection, such as ARI (acute respiratory tract infection), diarrhea, common cold, dengue, chickenpox, mumps, and hepatitis.

Results of body temperature monitoring (Figure 1) show that both groups had reduced fever below $38.5^{\circ} \mathrm{C}$ in the first hour. In the second hour a significant difference of body temperature reduction was observed, with the suppository group being able to reduce body temperature to a further extent than the oral group [mean temperature $37.54(\mathrm{SD} 0.6){ }^{\circ} \mathrm{C}$ vs. 37.87 $\left.(\mathrm{SD} 0.7){ }^{\circ} \mathrm{C}(\mathrm{P}=0.033)\right]$. The mean lowest body temperature reached by the suppository group was $37.40\left(\mathrm{SD} \mathrm{0.6)}{ }^{\circ} \mathrm{C}, 2.5\right.$ hours after the first observation, while that reached by the oral group was 37.50 (SD 0.8) ${ }^{\circ} \mathrm{C}$ during the $3^{\text {rd }}$ hour. The following rise of body temperature did not differ significantly between the two groups, and both groups returned to a body temperature of $38.5^{\circ} \mathrm{C}$ at the $6^{\text {th }}$ hour.
Comparison of the efficacy of oral and suppository ibuprofen is shown in Table 2 . The suppository reached the lowest body temperature significantly faster than oral ibuprofen [2.72 (SD 1.1) hours vs. 3.43 (SD 0.5) hours $(\mathrm{P}=0.05)$ ], with a mean difference of 0.71 hours or 40 minutes. The mean rate of body temperature reduction $\left(\delta \mathrm{t}^{\circ} / \mathrm{Wmax}\right)$ was 0.90 (SD 0.4) ${ }^{\circ} \mathrm{C} /$ hour for the suppository and 0.61 (SD $0.3){ }^{\circ} \mathrm{C} /$ hour for oral ibuprofen $(\mathrm{P}=0.001)$. However, the lowest body temperature reached and the duration for which body temperature was kept below $38.5^{\circ} \mathrm{C}$ did not differ significantly. The body temperature of one subject from the oral group did not drop to below $38.5^{\circ} \mathrm{C}$, so the duration of effectiveness was conducted on 74 subjects only.

During the six-hour observation period, one subject from the oral group was recorded to throw up twice. No special treatment was given and no further incident occurred after the parents stopped administering ibuprofen during the 24-hour home observation. 


\section{Discussion}

One possible explanation for the significant differences between both groups was the relatively higher dose of ibuprofen suppository. We could not administer a suppository dose equivalent to the oral dose since it was impossible to cut the suppository into parts. However, a study conducted by Kelley ${ }^{3}$ showed that a significant difference only occurred at a dose of $5 \mathrm{mg} / \mathrm{kg}$ body weight but not at $10 \mathrm{mg} /$ $\mathrm{kg}$ body weight.

Age, ranging from 2-5 years, was selected to avoid side effects that might occur in very young children (under 2 years old), although according to Mc Intyre et al ${ }^{7}$ ibuprofen is safe for infants as young as 2 months old. Eventhough the mean age of subjects in both age groups were different $(3$ years old in the oral group and 3.4 years old in the suppository group); it had no clinical relevance since both groups had similar anatomical and physiological conditions. The American Hospital Formulary Service (AFHS) medicine guide also states that there is no pharmacological difference in administering ibuprofen to children aged 2-11 years. ${ }^{8}$ A study by Kaufmann also found that age does not significantly affect absorption, elimination rate, or drug concentration. Different pharmacokinetics in younger children is caused by the difference in body surface area. $^{9}$

The pre-treatment body temperature did not differ significantly between the groups $\left(39.04^{\circ} \mathrm{C}\right.$ vs. $\left.39.18^{\circ} \mathrm{C}\right)$. This is a very important finding, considering the fact that $\delta \mathrm{t}^{\circ}$ or the difference between the pre-treatment and the lowest body temperature is one of the parameters for drug efficacy.

Most of the subjects were diagnosed as viral acute respiratory tract infection. This supports the inclusion criteria in limiting the length of the fever to less than 7 days, to guarantee that the fever was the one caused by infection instead of any other inflammatory disease.

According to AFHS, the peak plasma concentration of ibuprofen in plasma is reached at 1-2 hours. ${ }^{8}$ Mc Intyre et al, 7 who compared oral ibuprofen $7.5-10 \mathrm{mg} / \mathrm{kg}$ to paracetamol of various dosages, has shown that the lowest body temperature was reached in the $3^{\text {rd }}$ hour. However, Kelley, ${ }^{3}$ Walson PD, ${ }^{10}$ Amdekar, ${ }^{11}$ and Kauffmann ${ }^{9}$ reported that the lowest body temperature was reached between the $3^{\text {rd }}$ and $4^{\text {th }}$ hour. Kauffmann ${ }^{9}$ and Kelley ${ }^{3}$ reported that the maximum level reached after oral administration was at 40 minutes and $60 \pm 19.7$ minutes respectively. The above findings show that there is a gap between the time when the maximum plasma ibuprofen concentration is reached and that when the clinical antipyretic effect can be detected. The time needed by oral and suppository ibuprofen to reduce body temperature to the lowest point has a statistically significant difference with a mean difference of 40 minutes (0.71 hours). This finding does not concur with that of an earlier study by the Pharmacology Department, Medical School, University of Gadjah Mada, which stated that the maximum level of ibuprofen in blood after administering a suppository to adult volunteers was reached in the $2^{\text {nd }}$ hour, and took significantly longer than the oral treatment (40 minutes). ${ }^{12}$ The study by Maunuksela showed that in the $2^{\text {nd }}$ hour, there are also reductions of pain and heart rate after administering an Ibuprofen suppository to children post-operatively. ${ }^{13}$ The rate of body temperature reduction, which is measured as the degree of body temperature difference divided by the time it takes to reach the lowest body temperature $\left(\delta \mathrm{t}^{\circ} / \mathrm{W} \max \right)$, was in accordance with the above results, with the suppository group being slightly faster than the oral group $\left(0.9^{\circ} \mathrm{C} /\right.$ hour vs. $0.6^{\circ} \mathrm{C}$ /hour, $\left.\mathrm{P}=0.001\right)$. The reduction of body temperature from the pre-treatment level to the lowest point showed no significant difference $\left(1.99^{\circ} \mathrm{C}\right.$ for the oral group and $2.11^{\circ} \mathrm{C}$ for the suppository group, $\mathrm{P}=0.489$ ). The findings for the oral group did not differ greatly from other oral ibuprofen studies. $7,10,14$ The effective duration for which body temperature was maintained below $38.5^{\circ} \mathrm{C}$ showed no significant difference between both preparations (196.6 minutes for the oral group and 220.8 minutes for the suppository group, $\mathrm{P}=0.231$ ). This concurs with the references which state that ibuprofen will reduce body temperature for 3-4 hours. ${ }^{8,15,16}$ Research by Gianni et al ${ }^{17}$ showed that this duration was 3.79 hours. In our study, however, one subject never reached a body temperature below $38.5^{\circ} \mathrm{C}$.

The slower absorption rate for oral ibuprofen is expected because the drug must be absorbed intes- 
tinally, transported through the liver into the blood circulation. The same process will happen if suppository drugs are mostly absorbed by the superior or median hemorrhoid veins that go into the vena porta and perhaps even slower because the rectum's mucosa has a smaller surface area than the intestinal mucosa. ${ }^{5,18}$ However, if the suppository drug is absorbed mostly in the lower rectum, which is served by the inferior hemorrhoid vein, the drug will enter the inferior vena cava and produce a faster systemic reaction. ${ }^{18}$

The most frequent side-effect of ibuprofen as other non-steroid analgesic inflammatory drugs (NSAID), is gastrointestinal disturbance. However, this side effect is mostly well tolerated. ${ }^{8,16}$ Five to fifteen percent of patients who receive ibuprofen will have this side effect, although it is less likely to happen than when using aspirin. ${ }^{16}$ Side effects mostly occur in overdose conditions (intentionally or otherwise) or long term, for example, in use as an analgesic for rheumatism or other collagen diseases. ${ }^{19,20}$ Other studies comparing oral ibuprofen with oral aspirin in long term use ( 2 weeks) have recorded gastrointestinal side effects. ${ }^{17}$ Mc Intyre et al., who administered multiple dosages of ibuprofen in their study, found that six out of 77 patients suffered from vomiting, abdominal discomfort, and urticaria. ${ }^{7}$ Other studies which used a single dose of ibuprofen found that only one out of 64 subjects suffered from abdominal discomfort. ${ }^{3}$

It can be concluded that the efficacy of ibuprofen suppository is equal to that of oral ibuprofen, with the suppository resulting in a faster response.

\section{References}

1. Dinarello CA, Wolff SM. Pathogenesis of fever and the acute phase response. In: Mandell GL, Bennett JE, Dolin $\mathrm{R}$, editors. Principles and practice of infectious diseases. 4th ed. New York: Churchill Livingstone Inc; 1995. p. 530-6.

2. Abdoerrachman MH. Demam: Patogenesis dan pengobatan. In: Soedarmo SSP, Garna H, Hadinegoro SRS, editors. Buku ajar ilmu kesehatan anak, infeksi dan penyakit tropis. 1st ed. Jakarta: Balai Penerbit FKUI; 2002. p. 28-51.
3. Kelley MT, Walson PD, Edge JH, Cox S, Mortensen ME. Pharmacokinetics and pharmacodynamics of ibuprofen isomers and acetaminophen in febrile children. Clin Pharmacol Ther 1992;52:181-9.

4. Kokki H, Hendolin H, Maunuksela EL, Vainio J, Nuutinen L. Ibuprofen in the treatment of postoperative pain in small children. A randomized double blind placebo controlled parallel group study. Acta Anaesthesiol Scand 1994;38:467-72.

5. Van Hoogdalem E, de Boer AG, Breimer DD. Pharmacokinetics of rectal drug administration, part I. General consideration and clinical applications of centrally acting drugs. Clin Pharmakokinet 1991;21:11-26.

6. Committee on Drugs American Academy of Pediatrics. Alternative routes of drug administration, advantages and disadvantages [subject review]. Pediatrics 1997;100:143-52.

7. Mc Intyre J, Hull D. Comparing efficacy and tolerability of ibuprofen and paracetamol in fever. Arch Dis Child 1996;74:164-7.

8. American Hospital Formulary Service (AHFS). Drug Information . Ibuprofen. AHFS; 2003.

9. Kauffmann RE, Nelson MV. Effect of age on ibuprofen pharmacokinetics and antipyretic response. J Pediatr 1992;12:969-73.

10. Walson PD, Galletta G, Chomilo F, Braden NJ, Sawyer LA, Scheinbaum ML. Comparison of multidose ibuprofen and acetaminophen therapy in febrile children. AJDC 1992;146:636-2.

11. Amdekar YK, Desai RZ. Antipyretic activity of ibuprofen and paracetamol in children with pyrexia. British J Clin Prac 1985:39;140-3

12. Bagian Farmakologi Klinik Fakultas Kedokteran Universitas Gadjah Mada Yogyakarta. Ketersediaan hayati terbanding sediaan ibuprofen: Proris ${ }^{\circledR}$ supositoria $125 \mathrm{mg}$ vs Advil ${ }^{\circledR}$ sirup $100 \mathrm{mg} / 5 \mathrm{ml}$. Laporan penelitian. FKUGM; 1994.

13. Maunuksela EL, Ryhänen P, Janhunen L. Efficacy of rectal ibuprofen in controlling postoperative pain in children. Can J Anaesth 1992;39(3):226-30.

14. Autret E, Breot G, Jonville AP, Courcier S. Lassole C, Goehrs JM. Comparative efficacy and tolerance of ibuprofen syrup and acetaminophen syrup in children with pyrexia associated with infectious diseases and treated with antibiotic. Eur J Clin Pharmacol 1994;46:197201.

15. Furst DE, Munster T. Nonsteroidal anti-inflammatory drugs, disease-modifying antirheumatic drugs, nonopioid 
analgesics \& drugs used in gout. In: Katzung BG, editor. Basic and clinical pharmacology. 8th ed. New York: Lange Medical Books/McGraw-Hill; 2001. p. 596-623.

16. Flower RJ, Moncada S, Vane JR. Analgesic-antipyretics and anti-inflammatory agents. In: Goodman LS, Gilman AG, Rall TW, editors. Goodman and Gilman's the pharmacological basis of therapeutics. 8th ed. New York: Macmillan; 1993. p. 639-81.

17. Gianini EH, Brewer EJ, Miller ML, Gibbas D, Passo MH, Hoyeraal HM, et al. Ibuprofen suspension in the treatment of juvenile rheumatoid arthritis. J Pediatr
1990;117:645-52.

18. Coulthard KP, Nielson HW, Schroder M, Covino A, Matthews NT, Murray RS, et al. Relative bioavailability and plasma paracetamol profiles of Panadol suppositories in children. J Paediatr Child Health 1998;34:425-31.

19. Lee CY, Finkler A. Acute intoxication due to ibuprofen overdose. Arch Pathol Lab Med 1986;110:747-9.

20. Perrott DA, Piira T, Goodenough B, Champion D. Efficacy and safety of acetaminophen versus ibuprofen for treating children's pain or fever. Arch Pediatr Adolesc Med 2004;158:521 - 6 . 